\title{
CSR and indirect impacts of core business products/services of financial services institutions
}

\author{
George T.K. Thien \\ Faculty of Business and Law, \\ Auckland University of Technology, \\ New Zealand \\ Email: gtkthien@gmail.com \\ Email: george.thien@aut.ac.nz
}

\begin{abstract}
Financial services institutions (FSIs) are generally seen as organisations that have relatively minimal negative environmental impacts, compared to the heavy industrialised organisations. Their effort to minimise the direct environmental impacts as a result of their business processes is commendable, together with their highly publicised philanthropic/sponsorship activities. Whether FSIs should contribute even more positive social and environmental impacts through their core business products/services (indirect CSR impacts) has been less studied. Powerful FSIs have huge potential to make a difference because of their intermediary function that involves most if not all business organisations in the world. This paper examines the extent of reporting of indirect CSR impacts of FSIs' core business products/services. Literature review, content analysis and interviews were conducted to inform this study. There was evidence/admittance of lesser regard for indirect CSR impacts, despite an awareness of the huge potential for the powerful FSIs to influence global sustainability through their core business products/services.
\end{abstract}

Keywords: corporate social responsibility; CSR; financial services institutions; FSIs; direct impacts; indirect impacts; core business products/services.

Reference to this paper should be made as follows: Thien. G.T.K. (2016) 'CSR and indirect impacts of core business products/services of financial services institutions', Int. J. Corporate Strategy and Social Responsibility, Vol. 1, No. 1, pp.86-100.

Biographical notes: George T.K. Thien is a Senior Lecturer with Auckland University of Technology (AUT). He holds a BSc (Hons) in Economics and Accounting, a Master's of Business Administration, and a $\mathrm{PhD}$ related to corporate social responsibility. Having more than 20 years of business commercial and corporate experience, he is now an academic based with the Business and Law Faculty at AUT.

\section{Introduction}

It is commonly argued that business organisations, particularly large corporations, wield great power in society, with many commentators noting that this power should be exercised responsibly (Bakan, 2004; Banerjee, 2007; Korten, 2001; Thompson and Cowton, 2004). Lawrence et al. (2005, p.46) assert that a sense of corporate social 
responsibility (CSR) should compel a business organisation to be "accountable for any of its actions that affect people, their community, and their environment".

It is argued that financial services institutions (FSIs) are in a relatively powerful position to encourage CSR adoption and/or discourage anti-CSR activities by their clients, and so can provide overall benefits to society (Scholtens, 2006; Thompson and Cowton, 2004). According to Deepak (2014), CSR needed to be integrated into the core business process. Through their core business products/services, or indirectly through the activities of their clients, it is claimed that FSIs are powerful and influential and as such can have an enormous economic, social and environmental impact (Jeucken and Bouma, 2001; Scholtens, 2006). FSIs are important business organisations that perform an intermediary function in society that is a central feature in modern capitalism (Cowton, 2002; Scholtens, 2006). Prior and Argandona (2009) discuss how the performance of FSIs can substantially affect the gross domestic product (GDP) of a country.

The core business products/services of FSIs can facilitate both positive and negative economic, social and environmental impacts. 'The term 'core business products/services' of FSIs is used to represent mainly commercial bank loans and deposits, and insurance underwriting. The core business products/services referred to in this study represent the conventional 'bread and butter' business of these FSIs. Edwards (2005) calls for organisations whose products/services may raise direct or indirect harm to society and the environment "even if some cause and effect relationships are not fully established scientifically", to observe the precautionary principle. Non-governmental organisations (NGOs) have urged FSIs to adopt a precautionary approach or a 'do no harm' approach in their way of doing business (Green@work, 2003). That is, all impacts of actions or non-actions of organisations must be considered, a view similar to the broad perspective of CSR.

This paper contributes to previous work analysing CSR in the financial services sector for example, (Jain et al., 2015; Jeucken, 2001; Lachowicz, 2000; O'Sullivan and O'Dwyer, 2008), a currently under-investigated area of research (Lock and Seele, 2015; Coulson, 2007; O'Sullivan and O'Dwyer, 2008). The major contribution of this study however, is its empirical reinforcement of emerging critique relating to CSR as limited in what it currently achieves, and pretentious in terms of its rhetoric about taking responsibility for the society (Banerjee, 2007; Devinney, 2009). Specifically, it examines the reporting of indirect social and environmental impacts of New Zealand financial services institutions (NZFSIs), using content analysis of their voluntarily produced CSR reports, and some insights from CSR reporters and expert stakeholders. Unlike most previous studies that focussed on motivations for CSR reporting and or endeavours (e.g., Bowen, 2000; Cormier et al., 2004; O'Donovan, 2002; Amran and Haniffa, 2011; Brammer and Pavelin, 2008; Jain et al, 2015; Lock and Seele, 2015), this study looks at the extent of reporting on indirect CSR impacts, and motivation for selection of reported issues in the CSR reports. Specifically, it investigates the extent of FSIs' CSR reporting on FSIs' social and environmental impacts resultant from their core business products/services, compared to those due to non-core business products/services.

The structure of this paper follows on with first, a review of several studies about FSIs' power within society. Second, CSR concepts in relation to the broad and narrow perspectives are reviewed. Third, it describes CSR and CSR reporting in the context of FSIs. Fourth, the mode of data collection for this study is described. Fifth, the findings are presented/discussed followed by the conclusion, and some recommendations for future research. 


\section{Literature review}

Powerful organisations, such as FSIs are able to use strategies that help to avoid and neutralise pressure from organisations in the institutional field. They can even reverselegitimate or counter-influence these other organisations. Institutional theory, seen along the line of legitimacy theory arguments, is where an organisation conforms to external rules and norms in order "to increase stability, legitimacy, and access to resources" [Ball and Craig, (2010), p.283]. Riaz (2009) relates the 'reverse-legitimacy' concept to the 2008/9 global financial crisis and finds that FSIs are powerful and able to influence the institutional field, including regulatory institutions such as The Federal Reserve, and The Securities Commission in the US, to the point of twisting and reshaping the 'iron cage' from the inside in order to suit their preferences. According to Riaz (2009), the ability of powerful organisations, such as FSIs, to:

"Carry out decoupling or concealment confers advantages to these few organisations over others, since they are able to derive legitimacy from the institutions in the institutional field, and at the same time keep their technical or substantive aspects free to perform as necessary for efficiency reasons" (p.31)

FSIs are often large and powerful with the impacts of their lending, investments and underwriting stretching far and wide. Scott and John (2002) provide an example where a bank's financing of a dam project can have social and environmental impacts that affect many stakeholders. The power includes making demands of clients, for example, borrowers have to supply evidence to their bankers about their positive corporate sustainability impacts such as through their social and environmental assessment reports by independent authorities to support their loan applications (Coulson, 2002). FSIs can demand their clients comply with certain thresholds regarding social and environmental impacts, as a way to impact the global social and environmental issues.

A broad view of CSR has evolved and it entails organisations being responsible for broader social and environmental objectives (Gray et al., 1996; Welford, 2004). A broad view of CSR takes into consideration both direct and indirect economic, social and environmental impacts, while a narrow CSR view mainly considers the direct impacts (Shaw and Barry, 2001). FSIs are known to have less environmentally hazardous activities, and subsequent direct impacts, compared to businesses that are engaged in primary resource extraction or heavy manufacturing and construction industries. However, Thompson and Cowton $(2004$, p.199) note that "they can be seen as facilitators of industrial activity which causes environmental damage", through their intermediary function. Indirect impacts of FSIs' activities are thus generally far higher than their direct impacts.

The broad view of CSR is sometimes linked to the concept of "sustainability, or, as it is often called sustainable development" [Gray et al., (1996), p.61]. Sustainable development is defined by the United Nations' World Commission for Environment and Development $(1987$, p.8) as a system of development which "meets the needs of the present without compromising the ability of future generations to meet their own needs". Admitting that the terms are often used interchangeably, Bebbington and Gray (2001, p.584) differentiated 'sustainability' and 'sustainable development' by referring to the former as 'a state' and the latter as "a process by which human activity moves towards sustainability or maintains that state". What constitutes sustainability is contested. Yet, it would seem a highly desirable state. Its prioritisation is problematic because of the 
different views it implies (Bebbington and Gray, 2001; Buhr, 2007; Gray, 2010; Tregidga and Milne, 2006).

The narrow view of CSR, as proposed by Devinney (2009, p.44), states that "for those with a narrow concept of CSR, the corporation has little, if any, obligation to the society other than the creation of economic rents that can accrue to the stakeholders with recognised rights to those rents". Such a view of CSR "is dominated by the predominant need to make money for shareholders, to grow, make profits and seek economic efficiency" [Gray et al., (1996), p.57]. Although the main emphasis is on maximising shareholders' returns, the narrow view of CSR does allow room to possibly consider for other stakeholders as implied with words such as 'has little, if any, obligation to society' and 'CSR is dominated', rather than exclusively responsible to shareholders.

Whereas a narrow view of CSR accepts selective responsibilities leading to omission of some, the broad view of CSR embraces all responsibilities for economic, social and environmental impacts. For example, when an organisation focuses its responsibility on "costs and risk reduction, competitive advantage, reputation and legitimacy, and synergistic value creation" [Kurucz et al., (2008), p.85], then only the economic responsibility is considered. Such an orientation is considered as business-case CSR as there is a lesser concern for social and environmental impacts as a result of the organisation's activities. The broad view of CSR not only considers organisational responsibility for the full range of economic, social and environmental impacts, it takes account of stakeholders who may be impacted or can impact the organisation. Being selective in organisational responsibilities or in the choice of stakeholders to which it responds may tantamount to an incomplete operationalisation of CSR from the perceptive of broad CSR.

This study promotes a broad view of CSR where responsibilities relating to the economy, society and environment are included. CSR activities of business organisations in this view include all business activities that have direct and indirect economic, social and environmental impacts on all stakeholders (Shaw and Barry, 2001).

Emphasising the importance of not only considering direct but also indirect impacts as part of CSR, O'Sullivan and O'Dwyer (2008, p.554) suggest that FSIs have "significant roles to play in economic progression, environmental protection and social stewardship, through both direct and indirect influence on the companies they finance and support". Direct economic, social and environmental impacts of FSIs include consequences of initiatives taken that are, for example, to increase productivity, ensure a safe working environment, and reduce energy usage, water and paper through their office operational activities (Shaw and Barry, 2001). Jeucken and Bouma (2001, p.29) categorise these consequences and initiatives as "internal issues relating to the business processes within banks, while external issues are connected to the bank's products".

Jeucken and Bouma (2001) consider external issues to be those indirect economic, social and environmental impacts by the clients of the FSIs resulting from the use of core business products/services of the FSIs, for example, loans, investments and underwriting services. These core business products/services do not themselves pollute or cause communal inconveniences but it is the activities they permit on behalf of users or clients which can cause negative impacts. Matthew and Gelder (2001) observe that Friends of the Earth, an NGO, in its investigation of the public accounts of Asia Pulp and Paper revealed its dissatisfaction in loans being extended to such clients so as to cause pollution, thus suggesting that some stakeholders do have serious concerns about the indirect impacts of the products/services of FSIs. O'Sullivan and O'Dwyer (2008) allege 
that FSIs have a significant role to play in positively influencing these indirect impacts of their core business products/services.

There have been few studies on CSR reporting specific to FSIs relative to other industries that have direct impacts on human or natural resources. In their study of six banks' CSR reports, from four countries over a period of 2005-2011, Jain et al, (2015) found that the reporting standards have improved despite CSR reporting being a voluntary undertaking. Also based on categorising of 'themes' reported, Vilar and Simao (2015) found that there are recurring 'themes', such as 'workers' welfare' and 'corporate ethics" being reported across the regions that were studied. On the other hand, Lock and Seele (2015) found that CSR reporting practices by FSIs did not do as well as those from the chemical industry, as far as the investors' stakeholders are concerned. Zaghal and Ahmad (1990) found that $82 \%$ of CSR reports by Canadian banks included human resource, product, and business practices themes. Environmental disclosures were less popular, especially for the service industry sector, such as FSIs (Bowen, 2000; Brammer and Pavelin, 2008), where there is less visible environmental issues and therefore less stakeholder pressure. Tarna (2001, p.149) examined environmental reports from 12 FSIs and all reported issues about paper use, energy use, waste, recycling, transport, employee commuting, water use and carbon dioxide emissions, collectively called 'direct effects'. Tarna (2001) identified that the impacts from lending, insurance, and investment decisions, or the indirect impacts, had not been clearly and/or explicitly reported.

Cowton and Thompson (2000) observe that, despite their influential status, FSIs have been less than convincing in their environmental disclosures. For example, "the consideration of environmental issues in bank lending operations is prompted mainly by a concern to manage [business] risk rather than to exploit lending opportunities or as a means of fulfilling their social responsibilities" [Cowton and Thompson, (2000), p.215]. In another study, Thompson and Cowton (2004) found that banks had not made use of their powerful positions to require their clients to disclose environmental information that could help the banks in their CSR reporting. Banks, through their core lending activities, could be "seen as facilitators of industrial activity which causes environmental damages" would appear to "need appropriate information if they are to factor environmental issues into lending decisions" [Thompson and Cowton, (2004), p.99].

A study on social disclosures in the annual reports of six Irish and four international banks by Douglas et al. (2004) found that the Irish banks reported less information than the international banks. The social issues reported provided no quantifiable information, mainly addressed shareholders' concern, ignored issues such as public complaints received, legal challenges and employee satisfaction were considered 'at a fairly superficial level' [Douglas et al., (2004), p.394]. A notable difference between the Irish and the international banks is the disclosure on community involvement, where the Irish banks had the least information compared with disclosure on corporate governance and human resources, while the international banks had disclosure on community involvement as priority. In the examination of CSR reporting through media releases in four Australian banks' websites, Reinig and Tilt (2009) found that their primary focus of disclosure is related to community involvement and were aimed at the customers and the community. It was concluded that the four banks attempted to seek to satisfy the needs of two powerful groups of stakeholders. The choice of issues for reporting was selective.

Being selective of activities or issues for CSR reporting, especially those that can potentially enhance profitability can lead to being labelled as greenwashing. 'Greenwash' is an expression used by Tilt $(2007, \mathrm{p} .8)$ to denote the motivation to undertake CSR 
reporting by organisations as to "improve reputation without substantially changing practices, to placate and manipulate stakeholders and to gain competitive advantage, rather than out of any real concern for society and environment". Similar meaning has also been attached to 'greenwashing' by Athanasiou (1996) and Beder (2000). Owen et al. (2001) refer to the business-case rationale relating to CSR reporting as a 'corporate spin'. Some bank studies have also highlighted reputational risks that relate to 'dirty' borrowers (Coulson, 2002; Lundgren and Catasus, 2000). However, Scott and John (2002) found that banks are slow to include responsibilities such as indirect social and environmental impacts in their reporting. CSR reporting is an important way for business organisations to manage their impacts on the environment and community because it allows them to measure, track and improve their performance on specific social and environmental issues (Jupe, 2007).

\section{Methodology}

Content analysis of CSR reports and interview feedback about the choice of the issues in the reports implies a joint construction of meaning around understandings of CSR and selection of issues and espoused motivations related to CSR reporting. CSR reports are a means of non-verbal communication used by organisations to report their CSR activities and their economic, social and environmental impacts. The issues selected for inclusion in the CSR reports are chosen by key decision-makers within each organisation. Litovsky $(2005$, p.51) states that "any report is a lens through which an organisation is assessed and simultaneously an invitation to others to participate in its programmes". Twenty seven CSR reports from three NZFSIs (for years ranging from 2004 to 2013) were selected as sample for content analysis. This purposive and judgmental sampling, a non-probability method (Collis and Hussey, 2003; Coyle, 1997) resulted in the selection of NZFSIs that produce stand-alone New Zealand CSR reports, which included two banks and one insurance company. The insurance company and one of the banks were pioneers in voluntarily producing a New Zealand specific stand-alone CSR report. Each of the NZFSIs in the sample is referred to using a code - NZFSI\#1, NZFSI\#2 or NZFSI\#3. The reason for doing so is to assist in anonymising the reporting of data as agreed with the respective NZFSI.

The use of content analysis for this study is consistent with previous research conducted on CSR reports, although it is the examination of annual financial reports that has been more common. Examples of the former include Gray et al. (1996); Hackston and Milne (1996); Tsang (1998); Clarke and Gibson-Sweet (1999); O’Dwyer (2003). Lock and Seele (2015) used both the financial reports and web-based information. This study focuses on stand-alone CSR reports, rather than annual financial reports, because the objective is to examine the state of CSR reporting specifically which is unlike previous research that measures the extent of reporting on CSR issues compared with that of non-CSR issues, or volume of output (Unerman, 2000).

Gray et al. (1995) collected data about whether a disclosure was quantified in monetary or non-monetary measurements, and whether the disclosure could be audited. Gray et al. (1995) also applied content analysis techniques in their interpretation of sentences and information in reports, for example, whether the information was good, bad or neutral. Such application is more subjective. Similarly, in this study, the researcher interpreted and made a judgment as to whether a sentence described the phenomena 
under investigation. In addition to issues identification from sentences, content analysis was used to assess the degree (volume percentage) of disclosure by NZFSI respondents about indirect impacts of their core business products, services, and processes.

As opposed to physical and syntactical coding units that are insensitive to meaning, the propositional coding unit adopted in this study requires some judgment of meaning (Krippendorff, 2004). First, the qualitative assessment of each sentence in the CSR reports was made, as in Hackston and Milne (1996); then the space taken by those qualified sentences was correlated, by volume in terms of percentage of the page and subsequently aggregated for the whole CSR report. Examples of studies that correlate volume of CSR disclosures to annual reports include those by Adams et al. (1998), Deegan and Gordon (1996), and Deegan and Rankin (1996). For this study, the guiding principle developed for coding the reports was the affirmative answer to a question or coding unit. The question asked, 'Does the sentence explicitly discuss or describe any specific and resultant economic, social, environmental impacts or consequences caused by the core business products, and services (lending, investing, underwriting) and/or processes of this NZFSI?'

Mathews (1997) criticises content analysis methodology because it lacks reference to normative positions about what should be, as it involves the study of reports that currently exist or have existed. Neuendorf (2002, p.15) argues "content analysis summarises rather than reports all details concerning a message set". Thus some of the richness of the content is lost. As noted above, to make linkages and to address some of the limitations, content analysis was used in this research to summarise the extent of indirect economic, social and environmental impacts of the core business products, services, and processes in relation to CSR reporting, as reported by the NZFSIs. One of Unerman's (1999) conclusions in his review on content analysis is that there is little concurrence among those researchers who had undertaken CSR studies using content analysis about how content analysis should be done.

The content analysis on the CSR reports by the three NZFSIs was first conducted for the period 2004 to 2010, where an indication of the results was obtained. Then, some interviews with the NZFSI reporters were conducted in 2011 to provide further insights about the motivations for choices of issues included in the CSR reports. This was followed by more content analysis on CSR reports for the period of 2011 to 2013. The three respondents consisted of key decision-makers and designers of three respective NZFSIs' stand-alone CSR reports. The semi-structured interviews were about three hours each, where recordings and note taking were also used to supplement the verbal discourse. The purpose of the interviews was to gather information and discuss the NZFSIs respondents' understandings of the concept of CSR in the financial services sector context, and the FSIs' motivations for producing CSR reports. Examples of questions asked include, 'What is CSR in the context of FSIs?', 'What is the core business of FSIs?' Additionally, semi-structured interviews (three hours each) were also conducted with two expert stakeholders who are conversant with CSR reporting by NZFSIs context to obtain and discuss their perceptions about FSIs' CSR. 


\section{Findings and discussions}

\subsection{Content analysis - extent of reporting on indirect CSR impacts of core business products/services}

The coding unit, as defined by the qualifying question 'does the sentence explicitly discuss or describe any specific and resultant economic, social, environmental impacts or consequences caused by the core business products, and services (lending, investing, underwriting) and/or processes of this NZFSI?', scores an average of $9 \%$ for all standalone CSR reports in the sample. This means that less than one page in ten of each CSR report is devoted to reporting about the impacts of the NZFSI's core business products, services and processes. There are only minor differences in this respect as the average for NZFSI\#1, NZFSI\#2 and NZFSI\#3are $8.32 \%, 9.56 \%$ and $9.16 \%$ respectively.

Disclosure about issues related to the social and environmental indirect impacts of core business products/services is relatively low, considering the extensiveness of such impacts by the FSIs. The extent of disclosure is mainly attributed to environmental impacts caused by the core business processes (direct impacts) which include use of electricity in office buildings, vehicle petrol consumption, paper usage, recycling and business travel. These activities are considered internal issues (Jeucken and Bouma, 2001) and only have direct impacts (Shaw and Barry, 2001) on the society and the environment. This suggests that NZFSIs had adopted a narrow CSR perspective in their CSR reporting. It can be argued that FSIs should adopt a broader CSR perspective for their CSR reporting because of their powerful and influential position in society, and that the CSR reporting guides, for example the GRI, recommends it.

\subsection{Interview responses - awareness vs. practices of broad/narrow CSR}

Interview responses typically reflect on the awareness and concern for the social and environmental impacts of NZFSI core business products/services, for example loans, to specific groups of clients for particular projects.

The environmental impact is also affected by our indirect impact through our lending, and we have credit risk processes in place to assess the risk of somebody who comes to us asking for credit and in terms of the likely impact that they have on the environment, and there are some social aspects to that too. So, if we are financing an activity, say a mining operation, it's important to us to understand whether the person asking for the finance has been consulting with the community and is actually managing the impact on the community because, for example, if someone wanting to build a mine and hasn't, and that will displace a community or affect the community in some ways that the community was unhappy about, that would affect our lending decisions. Ok, we are not a signatory to the Equator Principles, and I can explain why. (NZFSI $\# 1)$

Two other respondents also referred directly to lending.

We are concerned about 'Are our lending products being used to undertake business that we think might be socially or environmentally harmful?' So we want to ensure, for example, that we are not lending for the purpose of, say, one of the very obvious ones would be the manufacturer of weapons. (NZFSI \#2) 
If we are financing the activity, say a mining operation, it's important for us to understand whether the person asking for finance has been consulting with the community and is actually managing the impact on the community. (NZFSI \#2)

There are also examples of interview responses that suggested organisational profit or business case related motivation for CSR as a priority over social and environmental concerns.

Concern about the bottom line predominant, and can be affected by competitions and negative publicity as shown by the following samples. But certainly since ten years ago, banks were saying, look, we are aware of that, but it's a very competitive market, and we don't want to be asking our clients to go through the extra hoops and loops from an environmental social responsibility point of view because they might go and get their money somewhere else. (NZFSI\#3)

Reporting negative social issues could have a negative impact on our bottom line. (NZFSI \#2)

Some businesses (customers of other NZFSIs) do not meet those sustainability criteria, and the typical example of that is not all our power stations have emissions standards that equal the compendium of standards of the international standard of practice guidelines. Now, all the Australian banks and all the investment banks in the state still lend to the coal businesses or those involved in the coal powered energy industry, and so do we (NZFSI \#1). NZFSIs are fully aware of their responsibility for social and environmental impacts of their core business products/services, in relation to CSR, but preferred to play down that responsibility for fear of loss of business. However, it could be argued that FSIs have tremendous power to influence a huge network of clients' social and environmental impacts through their core business products/services, through imposition and enforcement of sustainability criteria (Coulson, 2009).

The expert stakeholders were very aware and concern of NZFSIs' potential ability and power to influence their customers through their business policies, including through criteria for lending, investment and underwriting. Through such criteria, FSIs can choose who they want to do business with or assert some influence on the CSR behaviour of their customers. Both expert stakeholders were critical of FSIs' lack of action on socially responsible investment or lending, and they see a huge potential for more responsible influence.

A lot of these organisations have investment portfolios and they put [lend] money to other organisations but they don't have sustainability criteria for their investment. They don't have criteria about supporting renewable energy, fair trade, you know, all those kind of broad issues that go with sustainability. So they could be investing in companies that are destroying the environment. Often they don't really know exactly what the investors are doing. (ES \#1)

I think the core area for financial institutions is their ability to influence their supply chain - customers and suppliers - and they are organisations that are funding big projects, and they are making decisions on ways to invest or lend their money. So it's their influence on the other organisations that is very very key, I think. And if they require these organisations to have sound social/environmental practices, they will be able to make a big difference to social and environmental responsibilities. I think it's their ability to influence that is the key. They need to get this understanding of what's important to the stakeholders and what's important about their activities that impact socially and environmentally. The thing about banks is how they can influence the market 
through the power of investment and the challenge to remain competitive at the same time, you know, so I think that's the issue that they should be reporting on. (ES \#2)

In addition to the potential ability for NZFSIs to exercise CSR through their products/services indirectly, one expert stakeholder added that such responsibility is not exercised, and NZFSIs should realise the significant role they can and should play.

Current CSR reporting practices tend to divert the public's attention away from the impacts of NZFSIs' core business products/services, and seek to realign the public's expectations with a narrower CSR view focused more around achievements such as office-related operational activities and philanthropy-related activities. It could be argued that a narrow view of CSR is a form of CSR, and without the regulatory compulsion of adopting a broad view of CSR, FSIs appear to have been doing their fair share of CSR. It also appears that NZFSIs are powerful enough to determine their preferred modus operandi of reporting less on their indirect social and environmental impacts of their core business products/services. Istead of institutions forcing what NZFSIs' CSR report should contain, a reverse-legitimacy (Riaz, 2009) situation appears to occur. Whether the broad view of CSR agenda can be forced upon FSIs remains to be seen. It may be that NZFSIs are waiting for the wider public to become more interested in, and demand change towards a broader view of accountability for CSR in the context of FSIs. As leaders, the NZFSIs who participated in this research may well already enjoy some acclaim and have protected themselves against the possibility of being seen as illegitimate - or laggards if such a demand came to the fore. Another possibility is that doing much more than their competitors (i.e., demanding more scrutiny over clients' loans, investments and/or underwriting) may render these NZFSIs less attractive to clients and investors, and hence less competitive. This studyalso suggests that CSR reporting decision-makers in NZFSIs need to take the initiative to change their narrow application of the CSR concept to a broader one (Prior and Argandona, 2009; Scholtens, 2006; Thompson and Cowton, 2004).

With these decision-makers from the NZFSIs freely claiming their FSIs' motivations to do CSR reporting as business-case driven, this finding is similar to the conclusions about CSR reporting being done to gain some business advantage, or done with self-business interest as reported by Larrinaga-Gonzalez et al. (2001), Jupe (2007) and Souto (2009). Although authors such as Gray et al. (1996) and Milne (2002) purport that empirical evidence about business being purely accountable for economic gain is not easy to get, the interview response for this study gives a very positive assertion perhaps due to the guarantee of anonymity of the respondents.

FSIs' core business products/services provide an intermediary function in most societies, and therefore they have a responsibility to the society that is very critical (Lachowicz, 2000). Should NZFSIs enforce strict environmentally or socially related criteria for their major loans, investment and underwriting clients, the number of people affected by such enforcement, directly or indirectly will be substantial. Without regulation to that effect, the ideal situation seems unlikely. FSIs are unlikely to volunteer such initiatives without external coercion. Perhaps with consistent pressure and encouragement from regulatory bodies, NGOs and academics over a period of time, FSIs may ease their way to a broader application of CSR, including reporting.

Although both the NZFSIs and the expert stakeholder respondents openly concurred on the business-case rationale as a major motive for the former to undertake CSR reporting during the interviews, there is no suggestion that it is the only motive. 
However, the eager and enthusiastic comments offered during the interviews suggest a strong relationship between CSR reporting and the business-case rationale, compared with other motivations. For example, there was no response about coercion on the part of NGOs on the NZFSIs to publish CSR reports. The NZFSI respondents commented about not feeling any pressure from any stakeholder group to do CSR reporting except from the New Zealand Business Council for Sustainable Development (NZBCSD) which their organisations had voluntarily joined, and one of the membership requirements is to produce a CSR report within three years of membership. The legitimacy threat in relation to CSR reporting seems relatively low but institutional isomorphic forces, such as those from NZBCSD and competitors, suggest some influences. However, these influences are more focussed on the production of CSR reports, rather than on the issues reported in the CSR reports.

A broader application of CSR can reflect a truer social responsibility (Hasnas, 1998); otherwise there may be seen as a greenwash effect (Athanasiou, 1996; Beder, 2000; Tilt, 2007) or corporate spin (Owen et al., 2001) as perceived by some stakeholders. Constant and consistent stakeholder pressure, such as around highly publicised legal actions on FSIs' dealings with socially and environmentally dubious clients, could perhaps one day initiate FSIs and/or regulatory bodies to consider a broad view of CSR more seriously. The chance of such regulation appears remote because of the power that FSIs hold in economies of the world.

\section{Conclusions/further research}

This empirical study reveals a relatively low average reporting on impacts of core business products/services of $8.99 \%$ per CSR report for the period 2004 to 2013. It seems to suggest that NZFSIs consider social and environmental impacts of their core business products/services (indirect CSR impacts) are of a lesser priority. NZFSIs appear to have adopted a narrow view of CSR (business case) in their CSR reporting, at the same time, understood their responsibility in relation to the broad view of CSR, a view also alluded by the expert stakeholders. Considering the power of NZFSIs' potential to influence a substantial network of clients, the social and environmental impacts could be enormous. NZFSIs appear to be powerful enough to adopt a business-case rationale for CSR reporting, with lesser powerful stakeholders still unable to influence an adoption of a broader view of CSR in their CSR reporting. Although this conclusion is based on the CSR reports and some report designers, it does not make an overall statement about NZFSIs' preference for a narrow view of CSR. A different study that focuses more on the different stakeholder within the NZFSIs would be required to enlighten this area. It could also be useful to examine the various stakeholder groups' perception of CSR in relation to the social and environmental impacts of FSIs' core business products/services, and how best to measure those impacts. 


\section{References}

Adams, C.A., Hill, W-Y. and Roberts, C.B. (1998) 'Corporate social reporting practices in Western Europe: legitimating corporate behaviour?’, British Accounting Review, Vol. 30, No. 1, pp.1-21.

Amran, A. and Haniffa, R. (2011) 'Evidence in development of sustainability reporting: a case of developing country', Business Strategy and the Environment, Vol. 20, No. 3, pp.141-156.

Athanasiou, T. (1996) Divided Planet: The Ecology of Rich and Poor, Little, Brown and Company, Boston.

Bakan, J. (2004) The Corporation: The Pathological Pursuit of Profit and Power, Constable, London.

Ball, A. and Craig, R. (2010) 'Using neo-institutionalism to advance social and environmental accounting', Critical Perspectives on Accounting, Vol. 21, No. 4, pp.283-293.

Banerjee, S.B. (2007) Corporate Social Responsibility: The Good, the Bad, and the Ugly, Edward Elgar, Northampton, Massachusetts.

Bebbington, J. and Gray, R. (2001) 'An account of sustainability: failure, success and a reconceptualization', Critical Perspectives on Accounting, Vol. 12, No. 5, pp.557-588.

Beder, S. (2000) Global Spin: The Corporate Assault on Environmentalism, Green Books, Dartington, UK.

Bowen, F.E. (2000) 'Environmental visibility: a trigger of green organisational responsiveness? Business Strategy and the Environment. Vol. 9, No. 2, pp.92-107.

Brammer, S. and Pavelin, S. (2008) 'Factors influencing the quality of corporate environmental disclosure', Business Strategy and the Environment, Vol. 17, No. 2, pp.120-136.

Buhr, N. (Ed.) (2007) Histories of and Rationales for Sustainability Reporting, Routledge, New York.

Clarke, J. and Gibson-Sweet, M. (1999) 'The use of social disclosure in the management of reputation and legitimacy: a cross sectoral analysis of UK Top 100 companies', Business Ethics: A European Review, Vol. 8, No. 1, pp.5-13.

Collis, J. and Hussey, R. (2003) Business Research, Palgrave Macmillan, New York.

Cormier, D., Gordon, I.M. and Magnan, M. (2004) 'Corporate environmental disclosure: contrasting management's perceptions with reality', Journal of Business Ethics, Vol. 49, No. 2, pp.143-158.

Coulson, A.B. (2002) Benchmarking Study: Environmental Credit Risk Factors in the Pan-European Banking Sector, F\&C Asset Management, London.

Coulson, A.B. (2009) 'How should banks govern the environment? Challenging the construction of action versus veto', Business Strategy and the Environment, Vol. 18, No. 3, pp.149-161.

Coulson, A.B. (Ed.) (2007) Environmental and Social Assessment in Sustainable Finance, Routledge, London.

Cowton, C.J. (2002) 'Integrity, responsibility and affinity: tree aspects of ethics in banking', Business Ethics: A European Review, Vol. 11, No. 4, pp.393-400.

Cowton, C.J. and Thompson, P. (2000) 'Do codes make a difference? The case of bank lending and the environment', Journal of Business Ethics, Vol. 24, No. 2, pp.165-178.

Coyle, J. (1997) Exploring the Meaning of Satisfaction with Health Care: Towards a Grounded Theory, South Bank University, London.

Deegan, C. and Gordon, B. (1996) 'A study of the environmental disclosure practices of Australian corporations', Accounting and Business Research, Vol. 26, No. 3, pp.187-199.

Deegan, C. and Rankin, M. (1996) 'Do Australian companies report environmental news objectively? An analysis of environmental disclosures by firms prosecuted successfully by the environmental protection authority', Accounting, Auditing and Accountability Journal, Vol. 9, No. 2, pp.50-63. 
Deepak, P. (2014) 'CSR reporting: paving the way for organized monitoring', International Journal of Organizational Behaviour \& Management Perspectives, Vol. 3, No. 4, pp.1215-1218.

Devinney, T.M. (2009) 'Is the social responsible corporation a myth? The good, the bad, and the ugly of corporate social responsibility', Academy of Management Perspectives, Vol. 23, No. 2, pp.44-56.

Douglas, A., Doris, J. and Johnson, B. (2004) 'Corporate social reporting in Irish financial institutions', The TQM Magazine, Vol. 16, No. 6, pp.387-395.

Edwards, A.R. (2005) The Sustainability Revolution: Portrait of a Paradigm Shift, New Society Publishers Inc, Gabriola Island, Canada.

Gray, R. (2010) 'Is accounting for sustainability actually accounting for sustainability and how would we know? An exploration of narratives of organisations and the planet', Accounting, Organisation and Society, Vol. 35, No. 1, pp.47-62.

Gray, R., Kouhy, R. and Lavers, S. (1995) 'Methodological themes: constructing a research database of social and environmental reporting by UK companies', Accounting, Auditing and Accountability Journal, Vol. 8, No. 2, pp.78-101.

Gray, R., Owen, D. and Adams, C.A. (1996) Accounting and Accountability: Changes and Challenges in Corporate Social and Environmental Reporting, Prentice Hall, Harlow.

Green@work (2003) The Collevecchio Declaration on Financial Institutions and Sustainability, Green@work - Special Edition [online] http://www.greenatworkmag.com/gwsubaccess/ 03julaug/special1.html (accessed 7 July 2013).

Hackston, D. and Milne, M.J. (1996) 'Some determinants of social and environmental disclosures in New Zealand companies', Accounting, Auditing and Accountability Journal, Vol. 9, No. 1, pp.77-108.

Hasnas, J. (1998) 'The normative theories of business ethics: a guide for the perplexed', Business Ethics Quarterly, Vol. 8, No. 1, pp.19-42.

Jain, A., Keneley, M. and Thomson, D. (2015) 'Voluntary CSR disclosure works! Evidence from Asia-Pacific banks', Social Responsibility Journal, Vol. 11, No. 1, pp.2-18.

Jeucken, M. (2001) Sustainable Finance and Banking: The Financial Sector and the Future of the Planet, Earthscan Publications Ltd, Guildford, UK.

Jeucken, M. and Bouma, J.J. (Eds.) (2001) The Changing Environment of Banks, Greenleaf Publishing Limited, Sheffield.

Jupe, R. (2007) 'An analysis of disclosures in corporate environmental reports', Social and Environmental Accounting Journal, Vol. 27, No. 2, pp.8-11.

Korten, D.C. (2001) When Corporations Rule the World, Kumarian Press Inc and Berrett-Koehler Publishers Inc, San Francisco.

Krippendorff, K. (2004) Content Analysis: An Introduction to its Methodology, SAGE Publications, London.

Kurucz, E., Colbert, B.A. and Wheeler, D. (Eds.) (2008) The Business Case for Corporate Social Responsibility, Oxford University Press, Oxford.

Lachowicz, M. (Ed.) (2000) The Listening Banks: The Development of Stakeholder Relations with NGOs, Greanleaf Publishing Limited, Sheffield.

Larrinaga-Gonzalez, C., Carrasco-Fenech, F., Caro-Gonzalez, F.J., Correa-Ruiz, C. and Paez-Sandubete, J.M. (2001) 'The role of environmental accounting in organisational change: an exploration of Spanish companies', Accounting, Auditing \& Accountability Journal, Vol. 14, No. 2, pp.213-239.

Lawrence, A.T., Weber, J. and Post, J.E. (2005) Business \& Society: Stakeholders, Ethics, Public Policy NSW, McGraw Hill Australia Pty Limited, Australia.

Litovsky, A. (2005) 'Stakeholder engagement and NGO accountability: the new frontier for innovation', Accounting Forum, Vol. 6, No. 2, pp.45-52. 
Lock, I. and Seele, P. (2015) 'Analyzing sector-specific CSR reporting: social and environmental disclosure to investors in the chemicals and banking and insurance industry', Corporate Social Responsibility and Environmental Management, Vol. 22, No. 2, pp.113-128.

Lundgren, M. and Catasus, B. (2000) 'The banks' impact on the natural environment - on the space between 'what is' and 'what if', Business Strategy and the Environment, Vol. 9, No. 3, pp.186-195.

Mathews, M.R. (1997) 'Twenty-five years of social and environmental accounting research: is there a silver jubilee to celebrate?', Accounting, Auditing \& Accountability Journal, Vol. 10, No. 4, pp.481-531.

Matthew, E. and Gelder, W.V. (2001) Paper Tiger, Hidden Dragons, Friends of the Earth, London.

Milne, M.J. (2002) 'Positive accounting theory, political costs and social disclosure analysis: a critical look', Critical Perspectives on Accounting, Vol. 13, No. 1, pp.369-395.

Neuendorf, K.A. (2002) The Content Analysis Guidebook, Sage Publications, Thousand Oaks.

O'Donovan, G. (2002) 'Environmental disclosure in the annual report: extending the applicability and predictive power of legitimacy theory', Accounting, Auditing and Accountability Journal, Vol. 15, No. 3, pp.344-371.

O'Dwyer, B. (2003a) 'The ponderous evolution of corporate environmental reporting in Ireland: recent evidence from publicly listed companies', Corporate Social Responsibility and Environmental Management, Vol. 10, No. 1, pp.91-100.

O'Sullivan, N. and O'Dwyer, B. (2008) 'Stakeholder perspectives on a financial sector legitimation process: the case of NGOs and the equator principles', Accounting, Auditing and Accountability Journal, Vol. 22, No. 4, pp.553-587.

Owen, D.L., Swift, T. and Hunt, K. (2001) 'Questioning the role of stakeholder engagement in social and ethical accounting, auditing and reporting', Accounting Forum, Vol. 25, No. 3, pp.264-282.

Prior, F. and Argandona, A. (2009) 'Credit accessibility and corporate social responsibility in financial institutions: the case of microfinance', Business Ethics: A European Review, Vol. 18, No. 4, pp.349-363.

Reinig, C.J. and Tilt, C.A. (2009) 'Corporate social responsibility issues in media releases: a stakeholder analysis of Australian banks', Issues in Social and Environmental Accounting, Vol. 2, No. 2, pp.176-197.

Riaz, S. (2009) 'The global financial crisis: an institutional theory analysis', Critical Perspectives on International Business, Vol. 5, Nos. 1/2, pp.26-35.

Scholtens, B. (2006) 'Finance as a driver of corporate social responsibility', Journal of Business Ethics, Vol. 68, No. 1, pp.19-33.

Scott, P. and John, S. (2002) 'Banks look to indirect impacts', Environmental Finance, Vol. 1, No. 1, pp.22-23.

Shaw, W.H. and Barry, V. (2001) Moral Issues in Business, Wadsworth Thompson Learning, Belmont, CA, USA.

Souto, D.B.F. (2009) 'Crisis and corporate social responsibility: threat or opportunity?', International Journal of Economic Sciences and Applied Research, Vol. 2, No. 1, pp. -6-50.

Tarna, K. (Ed.) (2001) Reporting on the Environment: Current Practice in the Financial Services Sector, Greenleaf, Sheffield.

Thompson, P. and Cowton, C.J. (2004) 'Bringing the environment into bank lending: implications for environmental reporting', The British Accounting Review, Vol. 36, No. 2, pp.197-218.

Tilt, C.A. (2007) 'External stakeholders' perspectives on sustainability reporting', in Unerman, J., Bebbington, J. and O' Dwyer, B. (Eds.): Sustainability, Accounting and Accountability, Routledge, New York.

Tregidga, H. and Milne, M. (2006) 'From sustainable management to sustainable development: a longitudinal analysis of a leading New Zealand environmental reporter', Business Strategy and the Environment, Vol. 15, No. 4, pp.219-241. 
Tsang, E.W.K. (1998) 'A longitudinal study of corporate social reporting in Singapore: the case of the banking, food and beverages and hotel industries', Accounting, Auditing and Accountability Journal, Vol. 11, No. 5, pp.624-635.

Unerman, J. (1999) 'A critique of content analysis as a research method for corporate social reporting', Presented at the Meeting of the Critical Perspectives on Accounting 1999 Conference, Baruch College, City University, New York, http://dx.doi.org/10.1108/ 09513570010353756 [online] http://www.google.co.nz/search?q=cache:vLNRXk_bTAAJ: panopticon.csustan.edu/cp (accessed 26 March 2012).

Unerman, J. (2000) 'Reflections on quantification in corporate social reporting content analysis', Accounting, Auditing and Accountability Journal, Vol. 13, No. 5, pp.667-681.

Vilar, V.H. and Simao, J. (2015) 'csr disclosure on the web: major themes in the banking sector', International Journal of Social Economics, Vol. 42, No. 3, pp.296-318.

Welford, R. (2004) 'Corporate social responsibility in Europe and Asia', The Journal of Corporate Citizenship, Spring, Vol. 1, No. 13, pp.31-47.

World Commission for Environment and Development (WCED) (1987) Our Common Future: The Brundtland Report, Oxford University Press, Oxford.

Zaghal, D. and Ahmed, S.A. (1990) 'Comparisons of social responsibility disclosure media used by Canadian firms', Accounting, Auditing and Accountability Journal, Vol. 3, No. 1, pp.38-53. 